\title{
KATA SAPAAN KEKERABATAN BAHASA MELAYU JAMBI DI DESA TERITI KECAMATAN SUMAY KABUPATEN TEBO
}

\author{
Sabar Saputra $^{1}$, Sainil Amral ${ }^{2}$ \\ Program Studi Pendidikan Bahasa dan Sastra Indonesia, Fakultas Keguruan dan \\ Ilmu Pendidikan, Universitas Batanghari, \\ Jambi
}

sbrsaputra@gmail.com amralsainil@gmail.com

\begin{abstract}
This research aims at describing the shape and the use of greetings in Jambi Malay language kinship in Desa Teriti Kecamatan Sumay Kabupaten Tebo. By doing this research, it is expected that the greetings in Desa Teriti Kecamatan Sumay Kabupaten Tebo can be continuously preserced by the speakers. This research uses qualitative descriptive method. Qualitative descriptive method is used in conducting data and explaining it scientifically. The source of the research data is native speaker of Jambi Malay in Desa Teriti Kecamatan Sumay Kabupaten Tebo. In collecting the data, observation, well-organized interview, and record technique are used. From the result of the research, it can be concluded that there is a direct and indirect of greetings in Jambi Malay language kinship in Desa Teriti Kecamatan Sumay Kabupaten Tebo. The direct kinship which is related with blood line consists of 2 types in sequence starts from piyut, gedeh, kopet, datok, nyai, bak, mak, kolop, supek, piyut dan icit-icit-icit and secara tak berurutan yang terdiri dari abang wo, bah, adek, wo, mewo, pak ngah, mengah, busu, mesu, abang, mbok, nak, kolop, supek. Meanwhile the indirect kinship which is related to marriage line are abang, mak + nama anak tertua, nama diri, bak, mek, abang, mbok, nama diri, abang, mak + nama menantu. There are two functions of greetings in Jambi Malay language kinship in Desa Teriti Kecamatan Sumay Kabupaten Tebo, they are: to mark on other speakers and to defend social relationship between the speakers. The greetings in the beginning of the sentence is to mark on other speakers, while the greeting at the end of the sentence is to defent social relationship between speakers.
\end{abstract}

Keywbords: Greeting, Tebo Kinship, Jambi Malay language

\footnotetext{
${ }^{1}$ Mahasiswa Program Studi Pendidikan Bahasa dan Sastra Indonesia, Fakultas Keguruan dan Ilmu Pendidikan, Universitas Batanghari, Jambi

2 Dosen Program Studi Pendidikan Bahasa dan Sastra Indonesia, Fakultas Keguruan dan Ilmu Pendidikan, Universitas Batanghari, Jambi
}

Kata Sapaan Kekerabatan Bahasa Melayu Jambi di Desa Teriti Kecamatan Sumay Kabupaten Tebo 


\section{PENDAHULUAN}

Bahasa mempunyai peran yang sangat penting bagi kehidupan manusia, terutama sebagai alat untuk berkomunikasi dengan sesama manusia. Pemanfaatan potensi bahasa sebagai alat komunikasi dapat dilihat dalam berbagai kegiatan kehidupan bermasyarakat termasuk untuk bertegur sapa. (Pernando dan Ade Rahima, 2017:1). Bahasa digunakan masyarakat sebagai alat pergaulan antarsesama dan alat untuk menyampaikan buah pikiran (Rofii dan Hasibuan: 2019). Dengan bahasa seseorang dapat bertegur sapa, saling mengenal, dan bekerjasama antara satu dengan yang lainnya.

Pentingnya peranan bahasa di masyarakat untuk bertegur sapa menimbulkan berbagai variasi bahasa khususnya variasi bentuk sapaan. (Rahima,2002:3). Untuk mengetahui bagaimana bentuk bahasa dan variasi bahasa sebagai alat untuk bertegur sapa. Khusus dalam penelitian peneliti fokus pada variasi pemakaian bahasa untuk sapaan dipakai masyarakat Melayu Jambi.

Bahasa daerah merupakan bahasa yang dipakai oleh penutur bahasa yang tinggal di daerah tertentu (Pateda, 1987:55). Bahasa Daerah Melayu Jambi di Desa Teriti Kecamatan Sumay merupakan bahasa yang ada di daerah Desa Teriti yang digunakan sebagai alat komunikasi dalam proses sapa-menyapa oleh masyarakat Desa Teriti sekaligus untuk mempererat hubungan diantara mereka.

Kata sapaan merupakan kata yang digunakan untuk menyapa lawan bicara. Menurut Chaer (2011:107) kata sapaan adalah kata-kata yang digunakan untuk menyapa, menegur, atau menyebut orang kedua, atau orang yang diajak bicara. Kata sapaan muncul ketika orang-orang melakukan komunikasi.
Berdasarkan hasil wawancara peneliti dengan penutur asli bahasa Melayu Jambi yang bernama Datuk Abas yang merupakan mantan ketua adat Desa Teriti pada bulan Juli 2019, seseorang tidak dianggap sopan apabila menggunakan kata sapaan yang tidak sesuai dengan yang seharusnya digunakan untuk lawan bicara. Apabila seseorang salah menggunakan kata sapaan kepada orang yang lebih tua, maka lawan bicara akan tersinggung dan akan memberikan teguran kepada penyapa. Oleh sebab itu, peneliti ingin meneliti apa saja bentuk-bentuk kata sapaan kekerabatan dan bagaimana pemakaiannya. Berdasarkan hasil wawancara peneliti dengan penutur asli bahasa Melayu Jambi yang merupakan masyarakat di Desa Teriti Kecamatan Sumay Kabupaten Tebo pada bulan Juli 2019, anak zaman sekarang kurang memperhatikan pemakaian kata sapaan kekerabatan bahasa Melayu Jambi di Desa Teriti Keacamatan Sumay Kabupaten Tebo, kata sapaan kekerabatan yang menjadi ciri khas dari desa Teriti mulai diganti, karena masyarakat sudah banyak dipengaruhi oleh masuknya berbagai budaya sehingga mempengaruhi penggunaan kata sapaan kekerabatan asli daerah Desa Teriti. Penelitian seperti ini penting dan menarik untuk diteliti agar tidak terjadi kesalahan dalam pemakaian kata sapaan, peneliti juga melihat ada bentuk keunikan dari sapaan kekerabatan yang ada di daerah Desa Teriti Kecamatan Sumay Kabupaten Tebo.

Berdasarkan latar belakang yang telah dikemukakan, perlu dilakukan pengidentifikasian masalah yang terkait dengan topik yang akan dibahas. 1) Terdapat penggunaan kata sapaan yang tidak sesuai dengan yang seharusnya digunakan untuk lawan bicara sehingga lawan bicara akan tersinggung dan 
memberikan teguran kepada penyapa. 2) Anak zaman sekarang kurang memperhatikan dan mulai mengganti penggunaan kata sapaan kekerabatan bahasa melayu Jambi di Desa Teriti Kecamatan Sumay Kabupaten Tebo.

Dikarenakan keterbatasan waktu dan kemampuan peneliti dalam penelitian ini maka dibatasi fokus permasalahan hanya pada bentuk kata sapaan kekerabatan langsung dan tak langsung sesuai dengan pendapat Irmayani (2004) dan pemakaian kata sapaan kekerabatan sesuai dengan pendapat Biber (dalam Perdi, 2012).

Pertanyaan penelitian dalam penelitian ini, sebagai berikut.

1. Bagaimanakah bentuk-bentuk kata sapaan kekerabatan langsung dan tak langsung bahasa Melayu Jambi di Desa Teriti Kecamatan Sumay Kabupaten Tebo?

2. Bagaimanakah pemakaian kata sapaan kekerabatan bahasa Melayu Jambi di Desa Teriti Kecamatan Sumay Kabupaten Tebo?

Berdasarkan fokus dan pertanyaan penelitian, maka dapat ditentukan tujuan yang hendak dicapai dalam penelitian ini, sebagai berikut.

1. Mendeskripsikan bentuk-bentuk kata sapaan kekerabatan langsung dan tak langsung bahasa Melayu Jambi di Desa Teriti Kecamatan Sumay Kabupaten Tebo.

2. Mendeskripsikan pemakaian kata sapaan kekerabatan bahasa Melayu Jambi di Desa Teriti Kecamatan Sumay Kabupaten Tebo.

\section{Kajian Pustaka}

Bahasa adalah sebuah sistem, artinya, bahasa itu dibentuk oleh sejumlah komponen yang berpola tetap dan dapat dikaidahkan (Chaer dan Agustina, 2010:11). Sebagai sebuah sistem, bahasa itu bersifat sistematis juga bersifat sistemis. Sistematis maksudnya, bahasa itu tersusun menurut suatu pola terentu, tidak tersusun secara acak atau sembarangan. Sistemis, artinya, sistem bahasa itu bukan merupakan sebuah sistem tunggal, melainkan terdiri dari sejumlah subsistem, yakni subsistem fonologi, morfologi, sintaksis, dan leksikon. Setiap bahasa memiliki sistem yang berbeda dari bahasa yang lainnya. Oleh karena itu, lazim juga disebut bahwa bahasa itu bersifat universal. Unik artinya memiliki ciri atau sifat khas yang tidak dimiliki bahasa lain dan universal berarti, memiliki ciri yang sama yang ada pada semua bahasa.

Sudaryanto (1983:13) membagi bentuk bahasa menjadi dua, yaitu bahasa lisan dan tulisan. Bahasa tulis dianggap sebagai objek sekunder. Ini tidak mengherankan karena dari sebuah kalimat yang tertulis, terlalu sulit diterka apa yang tersirat dalam tulisan. Bahasa lisan dianggap sempurna karena yang sedang berbicara dapat menambahkan unsur-unsur suprasegmental pada ucapannya sehingga apa yang diucapkannya lebih jelas. Jadi, bagi seorang linguis bahasa lisanlah yang terpenting. Ini bukan berarti bahasa tulis tak dapat dipergunakan. Tidak demikian halnya. Bahasa tulis dapat melengkapi apa yang kita peroleh dari bahasa lisan. Bahkan kalau kita melakukan penelitian tentang suatu bahasa yang tidak mempunyai penuturnya lagi, maka bahasa tulislah yang diambil sebagai data. Makna adalah isi yang terkandung di dalam bentuk-bentuk tadi, yang dapat menimbulkan reaksi tertentu. Makna adalah pertautan yang ada diantara unsurunsur bahasa itu sendiri (Djajasudarma, 1999:5).

Fungsi bahasa pada umumnya yaitu: sebagai alat komunikasi atau alat perhubungan antar anggota-anggota masyarakat, suatu komunikasi yang diadakan dengan mempergunakan bunyi yang dihasilkan oleh alat ucap manusia 
(Keraf, 1984:17). Fungsi terpenting dari bahasa adalah sebagai alat komunikasi dan interaksi (Sobur, (dalam Dewi, 2013)). Sejalan dengan itu, fungsi bahasa adalah alat untuk berkomunikasi (Pateda, 1987:4).

Sosiolinguistik dapat dibagi atas dua bagian, yakni: a) mikro sosiolinguistik yang berhubungan dengan kelompok kecil misalnya sistem tegur sapa, b) makro sosiolinguistik yang berhubungan dengan masalah perilaku bahasa dan struktur sosial (Pateda, 1987:5).

Pragmatik adalah cabang ilmu bahasa yang mempelajari struktur bahasa secara eksternal yaitu bagaimana satuan kebahasaan itu digunakan dalam komunikasi (Rohmadi dan Wijana, 2011:4).

Rahardi (dalam Dinda, 2017) menjelaskan bahwa sosiopragmatik adalah ilmu yang mempelajari kondisi penggunaan bahasa manusia, yang pada dasarnya sangat ditentukan oleh konteks situasi yang mewadahi bahasa itu.

Bahasa Melayu Jambi adalah bahasa daerah yang digunakan oleh masyarakat Melayu Jambi. Bahasa Melayu Jambi digunakan sebagai alat komunikasi, untuk berinteraksi antara satu dengan lainnya dalam kehidupan sehari-hari baik secara lisan maupun tulis. Secara Historis masyarakat Jambi termasuk kelompok pemakai bahasa Melayu. Pada kenyataannya, bahasa Melayu dipakai untuk berkomunikasi antarsuku dan warga masyarakat secara nonformal, juga dipakai sebagai alat komunikasi resmi yang sarat dengan nilai-nilai budaya, seperti dalam upacara pertunangan, dan pernikahan. Menurut Rahima (2002:1) fakta sosial menunjukkan bahwa bahasa Melayu juga dipakai di ranah formal yakni untuk menyampaikan pesan-pesan pembangunan kepada masyarakatnya.
Kata sapaan adalah kata yang digunakan untuk menegur sapaa orang yang diajak berbicara (orang kedua) atau menggantikan nama orang ketiga. Menurut Kridalaksana (1978:14) kata sapaan ialah kata atau ungkapan yang dipakai dalam sistem tutur sapa. Pada dasarnya kata sapaan merupakan unsur bahasa yang paling penting dalam melakukan komunikasi, karena kata sapaan sangat berguna untuk memulai percakapan dalam suatu kegiatan komunikasi, baik itu dengan teman, keluarga, dan lain sebagainya.

Kridalaksana (dalam Pateda, 1987:69) menemukan tujuh jenis kata sapaan yaitu: istilah kekerabatan, nama diri, nama profesi/jabatan, epitet, gelar, pronomina persona, dan kata seru.

Bentuk sapaan merupakan bentuk kebahasan yang didalamnya dikenal adanya tingkatan penggunaan sapaan. Bentuk kata sapaan dibagi menjadi bentuk kata sapaan kekerabatan langsung dan kekerabatan tak langsung. Kata sapaan persaudaraan langsung adalah kata sapaan untuk menyapa kaum kerabat yang mempunyai hubungan persaudaraan langsung yang disebabkan oleh hubungan darah. Menurut Irmayani (2004:32) sapaan terhadap kerabat langsung itu ada dua jenis, yaitu tehadap kerabat yang berurutan dan kerabat yang tidak berurutan. Kekerabatan berurutan dalam keluarga adalah kekerabatan yang dimulai dari urutan datuk/nenek tue, uyuk laki/tina, datok/nenek, uwak/umak, сисu lelaki betina, cicit, dan antah, sedangkan kerabat yang tidak berurutan artinya orang orang yang masih memiliki ikatan darah baik karena satu orang tua, satu nenek, maupun satu kakek, misalnya mbok, adek, pak along, mak usu, pak we, pak mude, pupuan dan kemenakan. Kata sapaan persaudaraan tak langsung adalah kata sapaan untuk menyapa kerabat yang mempunyai hubungan persaudaraan, yang disebabkan oleh hubungan 
perkawinan. Menurut Irmayani (2004:43) laki, bini, menantu, mertua, ipar, biras, dan besan merupakan sapaan yang masuk ke dalam istilah kekerabatan tak langsung, yaitu kekerabatan yang disebabkan oleh ikatan perkawinan.

Menurut Biber (dalam Perdi, 2012) kata sapaan memiliki dua fungsi, yaitu untuk menandai lawan tutur dan mempertahankan hubungan sosial antarpenutur. Kata sapaan yang terletak diawal kalimat biasanya berfungsi untuk menandai lawan tutur, sedangkan kata sapaan yang terletak diakhir kalimat biasanya berfungsi mempertahankan hubungan sosial antarpenutur.

\section{METODE PENELITIAN}

Jenis penelitian yang digunakan pada penelitian ini adalah penelitian kualitatif. Penelitian kualitatif bersifat deskriptif yang artinya data dianalisis dan hasil analisisnya berbentuk deskripsi, fenomena, tidak berupa angka-angka. Penelitian ini juga dikategorikan sebagai penelitian deskriptif kualitatif. Istilah deskriptif itu menyarankan bahwa penelitian yang dilakukan semata-mata hanya berdasarkan pada fakta yang ada atau fenomena yang memang secara empiris hidup pada penutur-penuturnya, sehingga yang dihasilkan atau yang dicatat berupa perian bahasa yang biasa dikatakan sifatnya potret: paparan seperti adanya (Sudaryanto, 1988:62).

Tempat penelitian dilakukan di wilayah provinsi Jambi tepatnya di Desa Teriti Kecamatan Sumay Kabupaten Tebo selaku Desa yang menggunakan bahasa Melayu Jambi dalam berkomunikasi sehari-hari. Waktu penelitian ini selama enam bulan, terhitung tanggal 12 November 2019 sampai dengan tanggal 12 Mei 2020.

Data penelitian ini berupa ungkapan yang mengandung kata sapaan kekerabatan Bahasa Melayu Jambi. Sumber data dalam penelitian ini adalah informan sebagai penutur asli bahasa Melayu Jambi di Desa Teriti Kecamatan Sumay Kabupaten Tebo. Peneliti menetapkan informan pada penelitian ini dengan cara yaitu 1 orang berada di bagian barat, 1 orang di bagian selatan, 1 orang di bagian utara, 1 orang di bagian timur dan 2 orang di bagian pusat Desa Teriti dengan jumlah informan 6 orang. Djajasudarma (2006:22) menjelaskan informan dapat pula ditentukan jumlahnya berdasarkan arah mata angin (4 sampai 6 orang) ditambah dengan lokasi pusat (1 sampai 2 orang).

Teknik pengumpulan data yang digunakan dalam penelitian ini menggunakan tiga teknik, yaitu observasi, interviu, dan teeknik rekam. Adapaun untuk pengabsahan data, digunakan Teknik triangulasi.

Analisis data adalah upaya peneliti menangani langsung masalah yang terkandung pada data. Penanganan ini terlihat dari adanya tindakan mengamati data, menganalisis, mengklasifikasi, menguji hasil analisis, dan menemukan kaidah kebahasaan (Sudaryanto, 1993). Setelah data terkumpul langkah yang dilakukan selanjutnya ialah mengolah data dengan cara mendeskripsikannya.

\section{HASIL DAN PEMBAHASAN}

Berdasarkan hasil analisis data, maka diperoleh hasil bentuk kata sapaan dan pemakaian kata sapaan kekerabatan bahasa Melayu Jambi di Desa Teriti Kecamatan Sumay Kabupaten Tebo, sebagi berikut.

\section{A. Bentuk Kata Sapaan}

1. Bentuk Kata Sapaan Kekerabatan
Langsung Hubungan Darah
a. Kekerabatan Langsung Secara
Berurutan
Kata sapaan kekerabatan berurutan dalam keluarga terdiri dari: 
orang tua dari buyut, buyut, datuk/nenek, ayah/ibu, cucu, cicit dan antah.

1) Bentuk Kata Sapaan Kekerabatan terhadap Orang Tua Laki-laki dari Buyut

Kata sapaan kekerabatan di Desa Teriti Kecamatan Sumay Kabupaten Tebo untuk menyapa orang tua lakilaki buyut adalah piyut.

2) Bentuk Kata Sapaan Kekerabatan terhadap Ibu

Kata sapaan kekerabatan di Desa Teriti Kecamatan Sumay Kabupaten Tebo untuk menyapa ibu adalah mak, mek, mamak dan umi.

3) Bentuk Kata Sapaan Kekerabatan terhadap Cucu Laki-laki

Kata sapaan kekerabatan di Desa Teriti Kecamatan Sumay Kabupaten Tebo untuk menyapa cucu laki-laki terdiri dari cong, kolop dan nama diri.

\section{b. Kekerabatan Langsung Secara Tak Berurutan}

Kata sapaan kekerabatan tak berurutan artinya orang-orang yang masih memiliki ikatan darah baik karena satu orang tua, satu nenek maupun satu kakek yang terdiri atas, kakak, abang, adik, paman/bibi, sepupu dan kemenakan.

1) Bentuk Kata Sapaan Kekerabatan terhadap Kakak Perempuan

Bentuk Kata Sapaan Kekerabatan terhadap Kakak Perempuan yang Tertua

Kata sapaan kekerabatan di Desa Teriti Kecamatan Sumay Kabupaten Tebo untuk menyapa kakak perempuan yang tertua terdiri atas bah, mbok dan ayuk.

2) Bentuk Kata Sapaan Kekerabatan terhadap Kakak Laki-laki

Kata sapaan kekerabatan di Desa Teriti Kecamatan Sumay Kabupaten Tebo untuk menyapa kakak laki-laki yang tertua terdiri atas abang wo, abang ndek, abang teh, abang neng dan abang tam.

3) Bentuk Kata Sapaan Kekerabatan terhadap Saudara Laki-laki dari Ayah dan Ibu

Kata sapaan kekerabatan di Desa Teriti Kecamatan Sumay Kabupaten Tebo untuk menyapa saudara lakilaki yang tertua dari ayah dan ibu adalah wo dan pak wo.

\section{Bentuk Kata Sapaan Kekerabatan Tak Langsung Hubungan Perkawinan \\ Laki, bini, menantu, mertua, ipar,} biras, dan besan merupakan sapaan yang masuk ke dalam istilah kekerabatan tak langsung, yaitu kekerabatan yang disebabkan oleh ikatan perkawinan.

a. Bentuk Kata Sapaan Kekerabatan terhadap Suami

Kata sapaan kekerabatan di Desa Teriti Kecamatan Sumay Kabupaten Tebo untuk menyapa suami adalah abang, bak + nama anak tertua.

b. Bentuk Kata Sapaan Kekerabatan terhadap Mertua

Kata sapaan kekerabatan di Desa Teriti Kecamatan Sumay Kabupaten Tebo untuk menyapa mertua laki-laki terdiri dari bak, ayah, bapak, abi dan babe.

c. Bentuk Kata Sapaan Kekerabatan terhadap Besan Perempuan

Kata sapaan kekerabatan di Desa Teriti Kecamatan Sumay Kabupaten Tebo untuk menyapa besan perempuan yang tertua terdiri dari bah, mbok, ayuk dan mak + nama menantu.

\section{B. Pemakaian Kata Sapaan}

\section{Pemakaian Kata Sapaan Kekerabatan Langsung Hubungan Darah \\ a. Kekerabatan Langsung Secara Berurutan}


Kata sapaan kekerbatan berurutan dalam keluarga terdiri dari: orang tua dari buyut, buyut, datuk/nenek, ayah/ibu, cucu, cicit dan antah.

1) Pemakaian Kata Sapaan Kekerabatan terhadap Orang Tua Laki-laki dari Buyut

Berikut adalah contoh pemakaian kata sapaan kekerabatan Bahasa Melayu Jambi di Desa Teriti Kecamatan Sumay Kabupaten Tebo:

Piyut, nasi lah masak.

(Piyut, nasi sudah masak).

2) Pemakaian Kata Sapaan Kekerabatan terhadap Ibu

Berikut adalah contoh pemakaian kata sapaan kekerabatan Bahasa Melayu Jambi di Desa Teriti Kecamatan Sumay Kabupaten Tebo:

Mak, bak lah nunggu.

(Ibu, Ayah sudah menunggu)

3) Pemakaian Kata Sapaan Kekerabatan terhadap Cucu Laki-laki

Berikut adalah contoh pemakaian kata sapaan kekerabatan Bahasa Melayu Jambi di Desa Teriti Kecamatan Sumay Kabupaten Tebo:

Ko(lop), mano mak kau?

(Cucu, mana ibu kamu?)

\section{b. Kekerabatan Langsung Secara Tak Berurutan}

Kata sapaan kekerabatan tak berurutan artinya orang-orang yang masih memiliki ikatan darah baik karena satu orang tua, satu nenek maupun satu kakek yang terdiri atas, kakak, abang, adik, paman/bibi, sepupu dan kemenakan.

1) Pemakaian Kata Sapaan Kekerabatan terhadap Kakak Perempuan

Berikut adalah contoh pemakaian kata sapaan kekerabatan Bahasa Melayu Jambi di Desa Teriti Kecamatan Sumay Kabupaten Tebo terhadap kakak perempuan yang tertua.
Bah, lah bejemo kain tadi.

(Kakak, sudah dijemur pakaian tadi)

2) Pemakaian Kata Sapaan Kekerabatan terhadap Kakak Laki-laki

Berikut adalah contoh pemakaian kata sapaan kekerabatan Bahasa Melayu Jambi di Desa Teriti Kecamatan Sumay Kabupaten Tebo terhadap kakak laki-laki yang tertua.

Abang wo, honda bang wo ko koto nian.

(Abang, motor abang ini kotor sekali).

3) Pemakaian Kata Sapaan Kekerabatan terhadap Saudara Laki-laki dari Ayah dan Ibu

Berikut adalah contoh pemakaian kata sapaan kekerabatan Bahasa Melayu Jambi di Desa Teriti Kecamatan Sumay Kabupaten Tebo terhadap saudara laki-laki tertua dari ayah dan ibu.

Wo, bageh awak ko sen.

(Paman, minta saya uang)

\section{Pemakaian Kata Sapaan Kekerabatan Tak Langsung Hubungan Perkawinan}

Laki, bini, menantu, mertua, ipar, biras, dan besan merupakan sapaan yang masuk ke dalam istilah kekerabatan tak langsung, yaitu kekerabatan yang disebabkan oleh ikatan perkawinan.

a. Pemakaian Kata Sapaan Kekerabatan terhadap Suami

Berikut adalah contoh pemakaian kata sapaan kekerabatan Bahasa Melayu Jambi di Desa Teriti Kecamatan Sumay Kabupaten Tebo: Makanlah dulu Bak Kiki

(Makanlah dulu Suami)

b. Pemakaian Kata Sapaan Kekerabatan terhadap Mertua

Berikut adalah contoh pemakaian kata sapaan kekerabatan Bahasa Melayu Jambi di Desa Teriti Kecamatan Sumay Kabupaten Tebo terhadap mertua laki-laki. 
Bak, lah makan?

(Ayah sudah makan?)

c. Pemakaian Kata Sapaan Kekerabatan terhadap Besan Perempuan

Berikut adalah contoh pemakaian kata sapaan kekerabatan Bahasa Melayu Jambi di Desa Teriti Kecamatan Sumay Kabupaten Tebo terhadap besan perempuan yang tertua.

O mak Lia, mano lia.

(O ibunya lia, lia ke mana?

\section{Analisis Bentuk Kata Sapaan Kekerabatan Langsung Hubungan Darah}

Kata sapaan kekerabatan terhadap persaudaraan langsung ada dua jenis, yaitu kerabat yang berurutan dan kerabat yang tak berurutan.

\section{Analisis Kekerabatan Langsung Secara Berurutan}

Kata sapaan kekerbatan berurutan dalam keluarga terdiri atas, orang tua dari buyut, buyut, datuk/nenek, ayah/ibu, cucu, cicit dan antah.

a. Analisis Bentuk Kata Sapaan Kekerabatan terhadap Orang Tua Laki-laki dari Buyut

Kata sapaan yang digunakan di Desa Teriti Kecamatan Sumay Kabupaten Tebo untuk menyapa orang tua laki-laki dari buyut yaitu piyut. Menurut pendapat Irmayani (2004:33) piyut merupakan kata sapaan untuk menyapa orang tua lakilaki dari buyut laki-laki dan perempuan. Irmayani (2004:33) mengatakan bahwa piyut sama dengan datuk tue sementara di daerah Desa Teriti Kecamatan Sumay Kabupaten Tebo disapa piyut. Secara teori Desa Teriti memiliki sapaan yang khsusus.

b. Analisis Bentuk Kata Sapaan Kekerabatan terhadap Ibu
Kata sapaan yang digunakan di Desa Teriti Kecamatan Sumay Kabupaten Tebo untuk menyapa ibu memiliki beberapa bentuk yang terdiri dari mak, mek, mamak dan umi. Masyarakat desa Teriti biasanya menggunakan kata sapaan mak dan mek untuk menyapa ibunya. Menurut Irmayani (2004:37) mak dan mek merupakan kata sapaan yang sering digunakan oleh masyarakat untuk menyapa ibu. Irmayani (2004:37) mengatakan mak dan mek disebut umak, sementara di daerah Desa Teriti Kecamatan Sumay Kabupaten Tebo disebut mak, mek, mamak dan umi.

c. Analisis Bentuk Kata Sapaan Kekerabatan terhadap Cucu

Kata sapaan yang digunakan di Desa Teriti Kecamatan Sumay Kabupaten Tebo untuk menyapa cucu laki-laki yaitu cong, kolop dan nama diri. Untuk sapaan cong dan kolop merupakan panggilan kesayangan dari kakek dan nenek. Menurut Irmayani (2004:37) cong dan kolop merupakan kata sapaan untuk menyapa cucu laki-laki kesayangan. Irmayani (2004:37) mengatakan cong dan kolop disebut cucu' sementara di daerah Desa Teriti Kecamatan Sumay Kabupaten Tebo disebut cong, kolop dan nama diri.

\section{Analisis Bentuk Kata Sapaan Kekerabatan Secara Tak
Berurutan}

Kata sapaan kekerabatan tak berurutan artinya orang-orang yang masih memiliki ikatan darah baik karena satu orang tua, satu nenek maupun satu kakek yang terdiri atas, kakak, abang, adik, paman/bibi, sepupu dan kemenakan. 
a. Analisis Bentuk Kata Sapaan Kekerabatan terhadap Kakak Perempuan

Kata sapaan yang digunakan di Desa Teriti Kecamatan Sumay Kabupaten Tebo untuk menyapa kakak perempuan yang tertua adalah bah, mbok dan ayuk. Diantara ketiga bentuk kata sapan untuk menyapa kakak perempuan yang tertua mayoritas masyarakat desa teriti menggunakan sapaan bah dan mbok, sedangkan penggunakan sapaan Ayuk biasanya digunakan oleh masyarakat dengan status sosial sosial menengah ke atas. Menurut Irmayani (2004:38) bah, mbok, dan ayuk merupakan kata sapaan untuk menyapa kakak perempuan yang tertua. Irmayani (2004:37) mengatakan bah, mbok, dan ayuk disebut $\boldsymbol{m b o k}$, ementara di daerah Desa Teriti Kecamatan Sumay Kabupaten Tebo disebut bah, mbok, dan ayuk.

b. Analisis Bentuk Kata Sapaan Kekerabatan terhadap Kakak Lakilaki

Kata sapaan yang digunakan di Desa Teriti Kecamatan Sumay Kabupaten Tebo untuk menyapa kakak laki-laki yang tertua memiliki beberapa bentuk yaitu berdasarkan urutan kelahiran, bentuk fisik dan warna kulit seperti abang, abang wo, abang ngah, abang ndek, abang neng, abang tam dan abang teh. Menurut Irmayani (2004: 39) abang wo merupakan kata sapaan untuk menyapa kakak laki-laki yang paling tua. Irmayani (2004:37) mengatakan abang wo disebut abang, abang long, abang uteh dan abang neng sementara di daerah Desa Teriti Kecamatan Sumay Kabupaten Tebo disebut abang wo, abang ndek, abang teh, abang neng dan abang tam. c. Analisis Bentuk Kata Sapaan Kekerabatan terhadap Saudara Lakilaki dari Ayah dan Ibu

Kata sapaan yang digunakan di Desa Teriti Kecamatan Sumay Kabupaten Tebo untuk menyapa saudara laki-laki tertua dari ayah dan ibu yaitu pak wo, dan wo. Penggunaan kata sapaan pak wo biasanya memiliki suatu profesi sehingga ada sapaan bapak yang disingkat dengan pak dan wo merupakan urutan kelahiran yang tertua. Kata sapaan untuk menyapa saudara laki-laki tertua dari ayah dan ibu masyarakat desa Teriti lebih sering menggunakan sapaan wo. Menurut Irmayani (2004: 40) wo merupakan kata sapaan untuk menyapa saudara laki-laki yang tertua dari ayah dan ibu. Irmayani (2004: 40) menyamakan wo dengan sebutan pak along sementara di daerah Desa Teriti Kecamatan Sumay Kabupaten Tebo disebut wo dan pak wo.

\section{Analisis Bentuk Kata Sapaan Kekerabatan Tak Langsung Hubungan Perkawinan}

Laki, bini, menantu, mertua, ipar, biras, dan besan merupakan sapaan yang masuk ke dalam istilah kekerabatan tak langsung, yaitu kekerabatan yang disebabkan oleh ikatan perkawinan.

1. Analisis Bentuk Kata Sapaan Kekerabatan terhadap Suami

Kata sapaan yang digunakan di Desa Teriti Kecamatan Sumay Kabupaten Tebo untuk suami yaitu abang, bak + nama anak yang tertua apabila sudah memiliki anak. Masyarakat sering menggunaan sapaan abang apabila belum memiliki anak atau baru saja menikah. Penggunaan sapaan bak + nama anak yang tertua biasanya digunakan oleh keluarga yang sudah memiliki anak. Menurut Irmayani (2004: 43) abang 
merupakan kata sapaan untuk menyapa suami yang belum memiliki anak atau baru saja menikah. Irmayani (2004:43) menyebut abang, bak + nama anak dengan sebutan laki dan bapak + nama anak sementara di daerah Desa Teriti Kecamatan Sumay Kabupaten Tebo disebut abang, bak + nama anak.

2. Analisis Bentuk Kata Sapaan Kekerabatan terhadap Mertua

Kata sapaan yang digunakan di Desa Teriti Kecamatan Sumay Kabupaten Tebo untuk menyapa mertua laki-laki yaitu sesuai dengan sapaan yang digunakan oleh suami/istri seperti bak, ayah, bapak, abi dan babe. Menurut Irmayani (2004: 45) bak, ayah, bapak, abi dan babe merupakan kata sapaan untuk menyapa mertua laki-laki. Irmayani (2004: 45) menyamakan bak, ayah, bapak, abi dan babe dengan sebutan uwak sementara di daerah Desa Teriti Kecamatan Sumay Kabupaten Tebo disebut bak, ayah, bapak, abi dan babe.

3. Analisis Bentuk Kata Sapaan Kekerabatan terhadap Besan Perempuan

Kata sapaan yang digunakan di Desa Teriti Kecamatan Sumay Kabupaten Tebo untuk menyapa besan perempuan yang tertua yaitu mbok, bah, ayuk dan mak + nama menantu. Menurut Irmayani (2004: 46) mak + nama menantu merupakan kata sapaan untuk menyapa besan perempuan. Irmayani (2004: 46) menyebut mak + nama menantu dengan sebutan besan sementara di daerah Desa Teriti Kecamatan Sumay Kabupaten Tebo disebut bah, mbok, ayuk dan mak + nama menantu.

\section{Analisis Pemakaian Kata Sapaan Kekerabatan Langsung Hubungan Darah}

Kata sapaan kekerabatan terhadap persaudaraan langsung ada dua jenis, yaitu kerabat yang berurutan dan kerabat yang tak berurutan.

\section{Analisis Kekerabatan Langsung Secara Berurutan}

Kata sapaan kekerbatan berurutan dalam keluarga terdiri atas, orang tua dari buyut, buyut, datuk/nenek, ayah/ibu, cucu, cicit dan antah.

a. Analisis Pemakaian Kata Sapaan Kekerabatan terhadap Orang Tua Laki-laki dari Buyut

Berikut adalah contoh pemakaian kata sapaan kekerabatan Bahasa Melayu Jambi di Desa Teriti Kecamatan Sumay Kabupaten Tebo:

Piyut, nasi lah masak.

(Piyut, nasi sudah masak).

Kata piyut pada kalimat tersebut digunakan sebagai penanda lawan tutur karena kata sapaan kekerabatan terletak pada awal kalimat. Sesuai dengan pendapat Biber (dalam Perdi, 2012), maka ini disebut sebagai penanda lawan tutur.

b. Analisis Pemakaian Kata Sapaan Kekerabatan terhadap Ibu

Berikut adalah contoh pemakaian kata sapaan kekerabatan Bahasa Melayu Jambi di Desa Teriti Kecamatan Sumay Kabupaten Tebo:

Mak, bak lah nunggu.

(Ibu, Ayah sudah menunggu)

Mek, lagi ngapo?

(Ibu, lagi apa?)

Kata mak dan mek pada kalimat tersebut digunakan sebagai penanda lawan tutur karena kata sapaan kekerabatan terletak pada awal kalimat. Sesuai dengan pendapat Biber (dalam Perdi, 2012), maka ini disebut sebagai penanda lawan tutur. 
c. Analisis Pemakaian Kata Sapaan Kekerabatan terhadap Cucu

Berikut adalah contoh pemakaian kata sapaan kekerabatan Bahasa Melayu Jambi di Desa Teriti Kecamatan Sumay Kabupaten Tebo terhadap cucu laki-laki.

Ko(lop), mano mak kau?

(Cucu, mana ibu kamu?)

Kata lop pada kalimat tersebut digunakan sebagai penanda lawan tutur karena kata sapaan kekerabatan terletak pada awal kalimat. Sesuai dengan pendapat Biber (dalam Perdi, 2012), maka ini disebut sebagai penanda lawan tutur.

\section{Analisis Kekerabatan Langsung Secara Tak Berurutan}

Kata sapaan kekerabatan tak berurutan artinya orang-orang yang masih memiliki ikatan darah baik karena satu orang tua, satu nenek maupun satu kakek yang terdiri atas, kakak, abang, adik, paman/bibi, sepupu dan kemenakan.

1. Analisis Pemakaian Kata Sapaan Kekerabatan terhadap Kakak Perempuan

Berikut adalah contoh pemakaian kata sapaan kekerabatan Bahasa Melayu Jambi di Desa Teriti Kecamatan Sumay Kabupaten Tebo terhadap kakak perempuan yang tertua.

Bah, lah bejemo kain tadi.

(Kakak, sudah dijemur pakaian tadi)

Kata bah pada kalimat tersebut digunakan sebagai penanda lawan tutur karena kata sapaan kekerabatan terletak pada awal kalimat. Sesuai dengan pendapat Biber (dalam Perdi, 2012), maka ini disebut sebagai penanda lawan tutur.

2. Analisis Pemakaian Kata Sapaan Kekerabatan terhadap Kakak Lakilaki
Berikut adalah contoh pemakaian kata sapaan kekerabatan Bahasa Melayu Jambi di Desa Teriti Kecamatan Sumay Kabupaten Tebo terhadap kakak laki-laki yang tertua.

Abang wo, honda bang wo ko koto nian.

(Abang, motor abang ini kotor sekali).

Kata abang wo pada kalimat tersebut digunakan sebagai penanda lawan tutur karena kata sapaan kekerabatan terletak pada awal kalimat. Sesuai dengan pendapat Biber (dalam Perdi, 2012), maka ini disebut sebagai penanda lawan tutur.

3. Analisis Pemakaian Kata Sapaan Kekerabatan terhadap Saudara Lakilaki dari Ayah dan Ibu

Berikut adalah contoh pemakaian kata sapaan kekerabatan Bahasa Melayu Jambi di Desa Teriti Kecamatan Sumay Kabupaten Tebo terhadap saudara laki-laki tertua ayah dan ibu:

Pak wo, mewo manonyo?

(Paman, Bibi dimana?)

Wo, bageh awak ko sen.

(Paman, minta saya uang)

Kata Pak Wo dan Wo pada kalimat tersebut digunakan sebagai penanda lawan tutur karena kata sapaan kekerabatan terletak pada awal kalimat. Sesuai dengan pendapat Biber (dalam Perdi, 2012), maka ini disebut sebagai penanda lawan tutur.

\section{Analisis Pemakaian Kata Sapaan Kekerabatan Tak Langsung Hubungan Perkawinan}

Laki, bini, menantu, mertua, ipar, biras, dan besan merupakan sapaan yang masuk ke dalam istilah kekerabatan tak langsung, yaitu kekerabatan yang disebabkan oleh ikatan perkawinan.

1. Analisis Pemakaian Kata Sapaan Kekerabatan terhadap Suami 
Berikut adalah contoh pemakaian kata sapaan kekerabatan Bahasa Melayu Jambi di Desa Teriti Kecamatan Sumay Kabupaten Tebo. Makanlah dulu Bak Kiki

(Makanlah dulu Suami)

Kata bak kiki pada kalimat tersebut digunakan sebagai mempertahankan hubungan sosial antarpenutur bukan sebagai penanda lawan tutur karena kata sapaan kekerabatan terletak pada akhir kalimat. Sesuai dengan pendapat Biber (dalam Perdi, 2012), maka ini disebut sebagai mempertahakan hubungan sosial antarpenutur.

2. Analisis Pemakaian Kata Sapaan Kekerabatan terhadap Mertua

Berikut adalah contoh pemakaian kata sapaan kekerabatan Bahasa Melayu Jambi di Desa Teriti Kecamatan Sumay Kabupaten Tebo terhadap mertua laki-laki.

Bak, lah makan?

(Ayah sudah makan?)

Kata bak pada kalimat tersebut digunakan sebagai penanda lawan tutur karena kata sapaan kekerabatan terletak pada awal kalimat. Sesuai dengan pendapat Biber (dalam Perdi, 2012), maka ini disebut sebagai penanda lawan tutur.

3. Analisis Pemakaian Kata Sapaan Kekerabatan terhadap Besan Perempuan

Berikut adalah contoh pemakaian kata sapaan kekerabatan Bahasa Melayu Jambi di Desa Teriti Kecamatan Sumay Kabupaten Tebo terhadap besan perempuan yang tertua.

O mak Lia, mano lia.

(O ibunya lia, lia ke mana?

Kata mak Lia pada kalimat di atas digunakan sebagai penanda lawan tutur karena kata sapaan kekerabatan terletak pada awal kalimat. Sesuai dengan pendapat Biber (dalam Perdi,
2012), maka ini disebut sebagai penanda lawan tutur.

\section{SIMPULAN}

Pada umumnya masyarakat desa Teriti mengikuti aturan sapaan secara umum yang digunakan oleh masyakarat. Namun, ada beberapa sapaan khusus yang digunakan oleh masyarakat desa Teriti berdasarkan sapaan kesayangan, urutan kelahiran, bentuk fisik dan warna kulit.

Berdasarkan hasil analisis data diketahui bahwa hal-hal sebagai berikut: 1) kata sapaan kekerabatan langsung secara berurutan Desa Teriti Kecamatan Sumay Kabupaten Tebo yaitu: datok piyut, gedeh, kopet, buyut, nyai, bak ayah, bapak, abi, babe, mak, mek, mamak, umi, cong, kolop, supek, piyut dan icit-icit-cit, iyut-iyut-iyut ; 2) kata sapaan kekerabatan langsung secara tak berurutan Desa Teriti Kecamatan Sumay Kabupaten Tebo yaitu: mbok, abang dan abang uteh, adek, nama diri, bah, ayuk, ngah, mbok cik, abang wo, abang ndek, abang neng, abang tam, abang ngah, abang cik, kolop, supek, wo, pak wo, pak ngah, pandak, teh, petam, pammok, busu, pak cik, do, cik, mewo, mengah, meendak, meteh, metam, meyu, mentu, memok, mesu, mecik, mecek, cek dan mendek; 3) kata sapaan kekerabatan tak langsung Desa Teriti Kecamatan Sumay Kabupaten Tebo yaitu: bak + nama anak tertua, mak + nama anak tertua, nama diri, abang, mbok dan nama diri,. bak, mak, busu, cik, do, bah, ayuk, mecek dan mesu.

Pemakaian kata sapaan kekerabatan bahasa Melayu Jambi Di Desa Teriti Kecamatan Sumay Kabupaten Tebo memiliki dua fungsi yaitu untuk menandai lawan tutur dan untuk mempertahankan hubungan sosial antarpenutur. Apabila kata sapaan kekerabatan terletak diawal kalimat, 
maka berfungsi sebagai penanda lawan tutur, sedangkan apabila kata sapaan kekerabatan terletak diakhir kalimat maka berfungsi sebagai untuk mempertahankan hubungan sosial antarpenutur.

Perbedaan tersebut disebabkan oleh perbedaan wilayah antara Melayu Jambi dengan Melayu (Ketapang), walaupun sama-sama Melayu tetap saja memiliki ciri khas atau sapaan khusus setiap daerah, perbedaan tersebut juga disebabkan oleh masuknya pendatang dari luar wilayah Melayu ke wilayah Melayu Jambi sehingga mempengaruhi dan menambah kosakata terkait kata sapaan disetiap daerah dan perbedaan tersebut juga disebabkan oleh sifat bahasa yang bersifat arbitrer (manasuka).

\section{Saran}

Bahasa daerah Melayu Jambi khususnya di Desa Teriti merupakan bahasa yang digunakan oleh masyarakat untuk berkomunikasi antarpenutur, salah satunya menggunakan kata sapaan dalam bertutur sapa. Kata sapaan ini sangat penting dan perlu dilestarikan, melalui hasil penelitian ini penulis menyarankan kepada beberapa pihak, sebagai berikut.

1. Kepada pemerhati bahasa untuk kepentingan pemertahanaan bahasa Melayu Jambi jika perlu ada standarisasi tantang kata sapaan kekerabatan bahasa Melayu Jambi, agar kata sapaan yang ada dalam bahasa Melayu Jambi khususnya di daerah Sumay bisa dilestarikan oleh generasi-generasi berikutnya.

2. Kepada penutur bahasa Melayu Jambi khususnya terkait kata sapaan kekerabatan di daerah Desa Teriti Kecamatan Sumay Kabupaten Tebo terus dilestarikan oleh penuturnya.

3. Kepada peneliti bahasa selanjutnya untuk dapat mengkaji lebih lanjut mengenai kata sapaan kekerabatan ini sehingga lebih banyak data yang diperoleh terkait kata sapaan yang ada di daerah Melayu Jambi.

\section{DAFTAR PUSTAKA}

Arini, Azizah Dewi. (2013). Bentuk, Makna dan Fungsi Bahasa Tulis Media Sosial Sebagai Alat Komunikasi dan Interaksi pada Internet. Skriptorium, Vol. 2 (1).

Chaer, Abdul. (2011). Tata Bahasa Praktis Bahasa Indonesia. Jakarta: Rineka Cipta.

Chaer, Abdul.dan Leoni Agustina. (2010). Sosiolinguistik Pekenalan Awal. Jakarta: Rineka Cipta.

Damarsasi, Gusti Dinda. (2017). Kajian

Sosiopragmatik Kefatisan

Berbahasa Para Abdi Dalem

Keraton Yogyakarta. Tesis:

Universitas Sanata Dharma

Yogyakarta.

Djajasudarma, T Fatimah. (1999).

Semantik I: Pemahaman Ilmu

Makna. Bandung: PT Refita

Aditama.

Irmayani, Martina. (2004). Sistem Sapaan Bahasa Melayu Ketapang. Jakarta: Pusat Bahasa Depertemen Pendidikan Nasional.

Keraf, Gorys. (1984). Tata Bahasa Indonesia. Jakarta: Arnoldus.

Kridalaksana, Harimurti. (1978). Fungsi Bahasa dan Sikap Bahasa. Ende Flores: Nusa Indah.

Pateda, Mansoer. (1987). Sosiolinguistik. Bandung: Angkasa.

Pernando, E., \& Rahima, A. (2017). Analisis Kohesi Leksikal dalam Majalah Patriotik LPM Universitas Batanghari Edisi XVI JuliSeptember Tahun 2016. Aksara: Jurnal Ilmiah Pendidikan Bahasa dan Sastra Indonesia, 1(1), 1-10.

Rahayu, Siti Perdi. (2012). Bentuk dan Fungsi Sapaan Bahasa Prancis dalam Novel Poil De Carotte Karya 
Jules Renard. Penelitian

Humaniora. 19 (2).

Rahima, A. (2002). Sistem sapaan bahasa Melayu Jambi: laporan penelitian. Fakultas Keguruan dan Ilmu Pendidikan, Universitas Batanghari.

Rofii, Afif. dan Hasibuan, Rizka Rani. (2019) Interferensi Bahasa Batak Mandailing dalam Tuturan Berbahasa Indonesia Pada Acara Parpunguan Masyarakat Mandailing Kota Jambi. Aksara: Jurnal Ilmiah Pendidikan Bahasa dan Sastra Indonesia Vol. 3 No. 1 April 2019 aksara.unbari.ac.id/index.php/aksara/ar ticle/download/94/50.

Sudaryanto. (1983). Linguistik Esai tentang Bahasa dan Pengantar ke dalam Ilmu Bahasa. Yogyakarta: Gadjah Mada University Press.

Wijana, Dewa Putu dan Muhammad Rohmadi. (2011). Analisis Wacana Pragmatik: Kajian Pendapat dan Analisis. Surakarta: Yuma Pustaka. 